\title{
Studies on Process Development and Quality Evaluation of Sour Dough Bread
}

\author{
H.W. Deshpande, S.D. Katke* and Pathan M. Aziz Khan \\ Department of Food Microbiology and Safety, College of Food Technology, \\ VNMKV, Parbhani, India \\ *Corresponding author
}

Keywords

Sour dough,

Lactobacillus

plantarum,

Lactobacillus

brevis, Composite

flour, Sour Dough

bread

Article Info

Accepted:

18 January 2019

Available Online:

10 February 2019

\section{A B S T R A C T}

The present investigation focuses on standardization the process for sour dough bread and its quality evaluation. Dough was fortified with LAB culture (Lactobacillus plantarum and Lactobacillus brevis) at $0.1 \%\left(\mathrm{~T}_{1}\right)$, $0.15 \%\left(\mathrm{~T}_{2}\right)$ and $0.2 \%\left(\mathrm{~T}_{3}\right)$ level of incorporation. The product prepared was evaluated for color, flavour, taste, texture, appearance and overall acceptability using semi-trained panel members on 9 point hedonic rating. It can be concluded that the LAB culture can be used successfully in preparation of sour dough bread at the level of $0.15 \%$ without any undesirable changes in physical, chemical and organoleptic attributes of bread.

\section{Introduction}

Bread products and their production techniques differ widely around the world. The foremost quality characteristics of leavened wheat breads are high volume, soft and elastic crumb structure, good shelf life, and microbiological safety (Cauvain, 2003; Chavan and Jana, 2008). Sourdough has a natural, additive-free image and lactic acid bacteria have been used in food for thousands of years and are "generally regarded as safe"
(Magnusson et al., 2003). Sourdough is ancient way to improve flavor, texture and microbiological shelf life of bread, and is widely utilized in whole grain rye baking (Lorenz and Brummer, 2003). Sourdoughs are very complex biological ecosystems because of the microbial composition and all interactive effects among the bread-making processes and ingredients (Gobbetti et al., 1999). The majority of species regularly isolated from sourdough or used as sourdough starter belong, with only few exceptions, to 1 
of the 4 genera Lactobacillus, Pediococcus, Leuconostoc and Weissella. The highest number of different species ( $>23$ species) is found in the genus Lactobacillus. Most of the yeast preparations for sourdoughs often contain LAB, especially Lactobacilli rather than Pediococcus, Lactococcus and Leuconostoc spp. (Jenson, 1998), which contributes a little to the aroma development through acidification of the dough during limited processing period (Rothe and Ruttloff, 1983). Yeasts are often associated with LAB in sourdough and the yeasts/LAB ratio is generally 1:100 (Gobbetti et al., 1994; Ottogalli et al., 1996). The utilization of sourdough has fundamental effects on dough rheology. Sourdough fermentation causes decreased elasticity and viscosity, less elastic and softer doughs, effects being more pronounced with longer fermentation times (Clarke et al., 2004). In comparison to bread prepared with baker's yeast, the sourdough breads are characterized by moist, dense grains, and a rather chewy texture (Qarooni 1996). The application of sourdough to wheat breads has a positive impact on bread volume, which is a primary quality characteristic of bread (Collar et al., 1994; Clarke et al., 2004). The optimal use of sourdough can improve the taste and flavor of the bread (Rehman et al., 2006). The flavor of sourdough wheat bread is richer and more aromatic than wheat bread, a factor that can be attributed to the long fermentation time of sourdough (Brummer and Lorenz, 1991). The flavoring compound diacetylget produced in significant amounts by Lactobacillus plantarum and Pediococcus pentosaceus. The application of $\mathrm{LAB}$ in the form of sourdough has a positive effect on bread staling. One such effect is an improvement in loaf-specific volume, which is associated with the reduction in the rate of staling (Corsetti et al., 2001). Sourdoughassociated LAB produce many antimicrobial substances, such as organic acids, $\mathrm{CO}_{2}$, ethanol, hydrogen peroxide, diacetyl, fatty acids, phenyllactic acid, reuterin, and fungicins (Messens and De Vuyst, 2002). Also, Lactobacillus plantarum shows very broad antimicrobial activity, and the antifungal compounds 4-hydroxyphenlyllactic and especially phenyl lactic acids have been identified as responsible for fungal inhibition (Ryan et al.,2009). Sourdough-associated LAB are also effective against rope spoilage of bread induced by Bacillus spp., probably due to production of organic acids and other still unknown antibacterial substances (Valerio et al., 2008). At present, the sourdough is employed in the manufacture of breads, cakes, and crackers (Chavan and Chavan, 2011). The use of sourdough is useful for making bread products with an increased level of flavor compounds, ultimately increasing the evenness in the batches and customer satisfaction. Sourdough technology can also be useful to reduce or eliminate the level of preservatives often used in baked products, as sourdough has shown antibacterial and antimold activity. Thus, sourdough could be useful in serving mankind with wholesome, tasty, and convenient foods.

\section{Materials and Methods}

Composite flour $(70 \%$ of whole wheat flour and $30 \%$ refined wheat flour), Granulated cane sugar, Iodized salt, baker's compressed yeast, Shortenings were purchased from local market.

\section{Starter cultures}

Pure cultures of Lactobacillus plantarum and Lactobacillus brevis were purchased from National Chemical Laboratory, (NCL) Pune.

\section{Purity of the cultures}

The staining of the obtained pure cultures of Lactobacillus plantarum and Lactobacillus brevis was carried out by using Gram positive 
staining technique for their identification (Harley and Prescott, 2002).

\section{Preparation of starter culture}

The starter culture was prepared with the help of the method described by Ghadge et al., (2008) with suitable modifications.

\section{Preparation of MRS Medium}

All the ingredients were suspended in distilled water and heated to dissolve the medium completely. The medium was sterilized in autoclave at $15 \mathrm{lbs}$ pressure for 15 minutes (De Mann et al., 1960).

\begin{tabular}{|l|l|}
\hline Ingredients & g/ lit \\
\hline Proteose peptone & 10.0 \\
\hline Yeast extract & 5.0 \\
\hline Beef extract & 10.0 \\
\hline Dextrose & 20.0 \\
\hline Tween -80 & 1.0 \\
\hline Ammonium citrate & 2.0 \\
\hline Sodium acetate & 5.0 \\
\hline Magnesium sulphate & 0.1 \\
\hline Manganese sulphate & 0.05 \\
\hline $\begin{array}{l}\text { Di-potassium } \\
\text { phosphate }\end{array}$ & 2.0 \\
\hline
\end{tabular}

\section{Sub-culturing of pure culture}

The pure cultures i.e. Lactobacillus plantarum and Lactobacillus brevis were sub-cultured on slants prepared from MRS media in laminar flow. This was incubated at $37^{\circ} \mathrm{C}$ for 24 hours in incubator. After 24 hours there was growth on slant of cultures.

\section{Preparation of sourdough bread}

The production of sourdough bread was carried out in the Pilot Bakery Plant by using Lactobacillus brevis, Lactobacillus plantarum and Saccharomyces cerevisiae with some modifications in the method described in A.A.C.C. (2000). The recipe used for preparation of bread mentioned below in Table 1 and pure LAB cultures used in recipe in different concentration is mentioned in Table 2.

\section{Results and Discussion}

\section{Proximate analysis of flour}

It is observed from the Table 3 that obtained flour found to contain 12.50 per cent of moisture. The lower moisture content of composite flour justifies the suitability for long term storage without deterioration (Peter and James, 2000). The protein content was recorded to be 11.85 per cent. The higher protein content is important for strong elastic dough which having high water absorptive capacity, excellent gas holding properties and will yield bread with good volume, grain and texture (Kent and Evers, 1997). The observed values for crude fat and ash content were 1.80 and 1.53 per cent respectively. The results obtained in the present study for the analysis of composite flour are also in close agreement with Yun et al., (1996)

\section{Bread making quality parameters of flour}

It is evident from the above Table 4 that gluten content of flour was 11.14 per cent (On dry weight basis) and 31.54 per cent (On wet weight basis). The values clearly indicated that flour used was strong in nature. The alcoholic acidity of flour was $0.09 \%$ and the obtained results for sedimentation value of composite flour were $21.67 \mathrm{ml}$ which represent good quality of flour. The Falling number of flour represents the viscous behavior of flour due to present of $\alpha$-amylase. The obtained values of $278 \mathrm{sec}$ for falling number represent the freshness of flour. The results are in comparable with William et al., (1988). 


\section{Rheological characteristics of sourdough}

It is observed from present investigation that the water absorption of sample $T_{1}$ containing 0.1 per cent of LAB starter culture was 61.21 per cent which increased with increased level of starter culture and reached up to 62.03 per cent in sample $\mathrm{T}_{3}$ having 0.2 per cent of $\mathrm{LAB}$ starter culture. The water absorption of flour is an important factor influencing the handling properties and machinability of dough and is related to the quality of the finished baked product (Catterall, 1998). The arrival time is point where the top of curve reaches 500BU points and indicates the rate of absorption (min/BU). Arrival time for flour was recorded to vary in the range 1.94 (sample $\mathrm{T}_{1}$ ) to 1.91 (sample $\mathrm{T}_{2}$ ) which were lower than control $(2.0 \mathrm{~min})$ (Table 5). The departure time is the point at which the top of the curve goes below 500BU line, which indicates the point at which the gluten is breaking down and dough has become overmixed (Pomeranz, 1988). Sample C showed maximum time to break down (9.11) which decreased gradually with increasing level of LAB starter culture addition and the lowest departure time $(8.49 \mathrm{~min})$. The stability is time between arrival time and departure time and generally indicates the strength of flour which is function of gluten development (Collar et al., 1994). The results revealed that stability of sourdough decreased with the increase in the level of LAB starter. Highest dough stability was recorded for the control (5.01 $\mathrm{min})$, which gradually decrease from $\mathrm{T}_{1}$ (4.58 min), $\mathrm{T}_{2}(4.12 \mathrm{~min})$ and $\mathrm{T}_{3}(3.60 \mathrm{~min})$. The findings of present investigation are similar with Hoseney (1994). Peak time reads the highest point on the curve and indicates the point they reached its maximum viscosity before gluten strands begin to breakdown (Pomeranz, 1988). Peak time values decreased with increase the level of LAB starter addition viz. 3.20, 3.17, 3.09 and 2.80 min for control, $\mathrm{T}_{1}, \mathrm{~T}_{2}$ and $\mathrm{T}_{3}$ respectively.
These findings are in good conformity with the results of (Wehrle et al., 1997). Softening of dough (SD) varied from 70.39, 90.01, and 120.33 BU for the samples $T_{1}, T_{2}$ and $\mathrm{T}_{3}$ respectively. These findings revealed that dough became softer with the increase in the level of LAB starter. These values are in close agreement with the findings of Schober et al., (2003).

It is evident from the Table 6 that highest value for mean distance at maximum force extensibility was noted for sample $\mathrm{T}_{2}$ (i.e. $42.7 \mathrm{~mm}$ ) followed by $\mathrm{T}_{1}$ and control (i.e. 38.1 and $37.2 \mathrm{~mm}$ respectively) whereas lowest value was noted for sample $\mathrm{T}_{3}$ viz. $34.4 \mathrm{~mm}$. Sample $T_{2}$ is best in extensibility over all other samples. The declined extensibility in sample $T_{3}$ can be attributed to presence of high concentration of organic acids that substantially decrease mixing time and weaken the dough (Wehrle et al., 1997). The extensibility graph showing the effect of addition level of LAB starter culture is illustrated in Figure 1.

\section{Physical properties of Sour Dough Bread with different levels LAB starter culture}

It is evident from the Table 7 that loaf volume showed significant variation as a result of treatments. Loaf volume of control sample was recorded to be $586 \mathrm{ml}$. samples $\mathrm{T}_{1}$ and $\mathrm{T}_{2}$ showed maximum volume viz. 587 and 590 $\mathrm{ml}$ respectively, followed by $\mathrm{T}_{3}$ which produced minimum volume i.e. $583 \mathrm{ml}$. Thus it may be concluded that sample $\mathrm{T}_{2}(0.15$ per cent LAB starter) was able to produce superior loaf volume. These results in the present study are in line with the findings of Corsetti et al., (2000). Similarly, the specific volume of the bread samples was calculated and the best treatment in this regard was found to be in sample $T_{2}\left(3.88 \mathrm{~cm}^{3} / \mathrm{g}\right)$ whereas, $\mathrm{T}_{3}$ sample was having the lowest specific volume viz., $3.80 \mathrm{~cm}^{3} / \mathrm{g}$. The results 
pertaining to the specific volume of bread indicated that treatment resulted in breads with less density and high volume and hence, preferred by the consumers. The results obtained in present investigation are in close agreement with the findings of Salim-urRahman et al., (2007). Crust to crumb ratio was found to be in the range of 0.255 to 0.263 with control sample having 0.255 value for crust to crumb ratio, the highest value was obtained by sample $T_{3}$ while sample $T_{1}$ showed lowest value. The values obtained for crust to crumb ratio indicated that there was no much difference found in these values as no effect of different incorporation level of LAB starter culture on the crust to crumb ratio. These findings are comparable with those of Taranto (1983).

Effect of different incorporation level of LAB starter culture on external sensorial characteristics of sour dough bread

It is evident from the Table 8 that amongst various external characteristics, volume of bread, crust color, symmetry of form, character of crust, crumb color and aroma were significantly affected by the different levels of LAB culture (Fig. 2). The volume of bread was found to increase with increase in concentration of LAB starter culture (from control to $\mathrm{T}_{3}$ ) and maximum volume was observed in sample $\mathrm{T}_{2}$ containing 0.15 per cent of LAB starter culture. The volume then decreased with further addition of starter culture as seen in sample $\mathrm{T}_{3}$. Crust color is an important sensory parameter concerning the consumer's acceptability of bread. Maximum score for the colour of crust in treated sample was obtained by sample $\mathrm{T}_{2}$ (i.e. 8.07). This might be due to the production of lactic acid which improved bread color (Tarar, 1999). The 'Symmetry of form' is an important bread parameter in deciding the characteristics like uneven top, low ends and shrunken sides of the bread. It is observed form Table 8 , symmetry of breads prepared from different starter cultures increased non significantly with the increase in addition of LAB starter culture. The 'evenness' of bake reflects that all sides including top and the bottom are uniformly baked and it also reflects the intensity of baking whether the sides having lighter or darker shade. The mean values for the evenness of bake of breads given in Table 8 indicated that evenness of bake among breads varied from 7.34 to 7.38 prepared from different level of LAB starter cultures. The 'character of crust' represents the hardness of bread crust. Higher curst hardness represents superior quality as it can sustain minor impact or attrition during transportation and handling. Addition of LAB starter culture does not have significant impact on the character crust of bread. The results in the Table 8 indicate that the scores assigned to aroma of breads ranged from 7.12 to 7.89 among the breads prepared from different level of starter cultures. The breads prepared from $\mathrm{T}_{3}$ got significantly higher score (i.e. 7.89). However, the lowest scores for the aroma were given to breads produced from $\mathrm{T}_{1}$ and $\mathrm{T}_{2}$ followed by control. The results of present study are in conformity with the findings of Martinez (1996). It is observed that the 'overall acceptability' in terms of external characteristics of bread improved linearly with increase in concentration of LAB starter culture and maximum score was secured for sample $T_{2}$ containing 0.15 per cent of LAB starter. The Sour Dough provides aromatic and pleasing flavor, and improves overall acceptability and shelf life of whole grain breads (Katina et al., 2005).

\section{Effect of different levels of LAB starter culture on internal characteristics of sour dough bread}

It was found that $\mathrm{LAB}$ starter culture results in enhancement of grain formation. Maximum grain score was obtained by the sample $T_{2}$ 
while control sample got the minimum score. These findings are similar with those obtained by Katina et al, (2006). LAB starter culture addition found to improve the color of crumb with sample $T_{2}$ obtaining the highest score. Maximum score for 'taste' was noted in the sample $T_{2}$ followed by $T_{3}$ and $T_{1}$ while the control sample scored the lowest value. The results for taste scores of Sour Dough bread were much higher than that of control breads, which suggested that the addition of Sour Dough improved the bread's taste. The scores for taste in the present study are in agreement with the findings of Siddique (1989). Textural properties of all the samples were found to increase with increase in concentration of LAB starter culture. The Sour Dough addition resulted in softer breads than control. Maximum textural scores were secured by sample $\mathrm{T}_{2}$ while the minimum values were observed in control sample $\mathrm{C}$. The desirable texture obtained by sample $\mathrm{T}_{2}$ was soft and pliable. The results of the present study are in concordance with the findings of Crowley et al., (2002) who found that the breads containing Sour Dough starter culture maintained superior textural properties. The 'overall acceptability' for internal characteristics of bread found to increase with increase in LAB starter culture concentration, however maximum score for overall acceptability was also observed in sample $\mathrm{T}_{2}$ having 0.51 per cent of LAB starter culture. The results obtained in the present study are in agreement with the findings of Shah et al., (1999) (Fig. 3 and Table 9).

\section{Effect of different level of addition of LAB starter culture on $\mathbf{p H}$ and titrable acidity of sour dough bread}

The mean values for the $\mathrm{pH}$ and titrable acidity of Sour Dough breads are given in Table 10, showing that yeast leavened control bread showed the highest $\mathrm{pH}$ (5.4) and the lowest acidity (2.75) values. The $\mathrm{pH}$ of Sour
Dough bread decreased with an increase in level of LAB starter culture with $\mathrm{T}_{1}, \mathrm{~T}_{2}$ and $\mathrm{T}_{3}$ $\mathrm{pH}$ value to be $4.5,4.1$ and 3.9 respectively. It may be due to the acidification of dough by LAB starter culture. The results for $\mathrm{pH}$ and acidity are in accordance with findings of Park et al., (2006).

Chemical composition of bread prepared with different addition level of LAB starter culture

The results for moisture content of breads prepared from different level of LAB starter cultures as given in Table 11 indicated that moisture content increased significantly with the increase in addition of LAB starter culture. The results indicated that breads prepared from control sample showed the lowest moisture content (31.02 per cent). Sample $\mathrm{T}_{3}$ possessed the highest moisture content (36.53per cent) followed by $T_{2}$ (35.80per cent) and $\mathrm{T}_{1}$ (35.13 per cent). The results of the present study are also in conformity with the findings of Corsetti et al., (2001). The breads were a good source of protein $(8.02 \pm 0.2)$, low in fat $(0.81 \pm 0.1)$, ash content $(2.01 \pm 0.04)$ and higher in the crude fiber $(9.91 \pm 0.01)$. These findings conforms the earlier study of Dubravka et al., (2011). It is observed from the Table that resistant starch of breads increased significantly with increase in the addition level of LAB starter culture. Control sample showed the lowest content of RS (3.21 per cent). Sample $\mathrm{T}_{3}$ showed the highest content of RS (6.04 per cent) followed by $T_{2}\left(5.54\right.$ per cent) and $T_{1}$ (4.76 per cent). This is in accordance with Brighenti et al., (1998).

Effect of different addition level of LAB starter culture on organic acid content of bread

The Sour Doughs bread of sample $\mathrm{T}_{3}$ yielded significantly the highest lactic acid content 
$(0.493 \mathrm{~g} / 100 \mathrm{~g})$ followed by the Sour Doughs of sample $T_{2}$ and $T_{1}$ having lactic acid to be 0.350 and $0.224 \mathrm{~g} / 100 \mathrm{~g}$ respectively. The production of lactic acid increased significantly by increasing the addition level of LAB starter cultures. The lactic acid content found in the Sour Doughs is similar to the study reported by Robert et al., (2005). The acetic acid content of Sour Doughs of sample $T_{3}$ produced significantly the highest acetic acid content $(0.093 \mathrm{~g} / 100 \mathrm{~g})$ followed by $\mathrm{T}_{2}(0.072 \mathrm{~g} / 100 \mathrm{~g})$ and $\mathrm{T}_{1}(0.041 \mathrm{~g} / 100 \mathrm{~g})$. The acetic acid was found to be least in the control sample i.e. $0.01 \mathrm{~g} / 100 \mathrm{~g}$. The results indicated that the production of acetic acid increased significantly with the increased addition level of starter cultures. The results of the present study are in agreement to the findings of Katina (2004) (Table 12).

Flowsheet-1: Preparation of bread by addition of sourdough

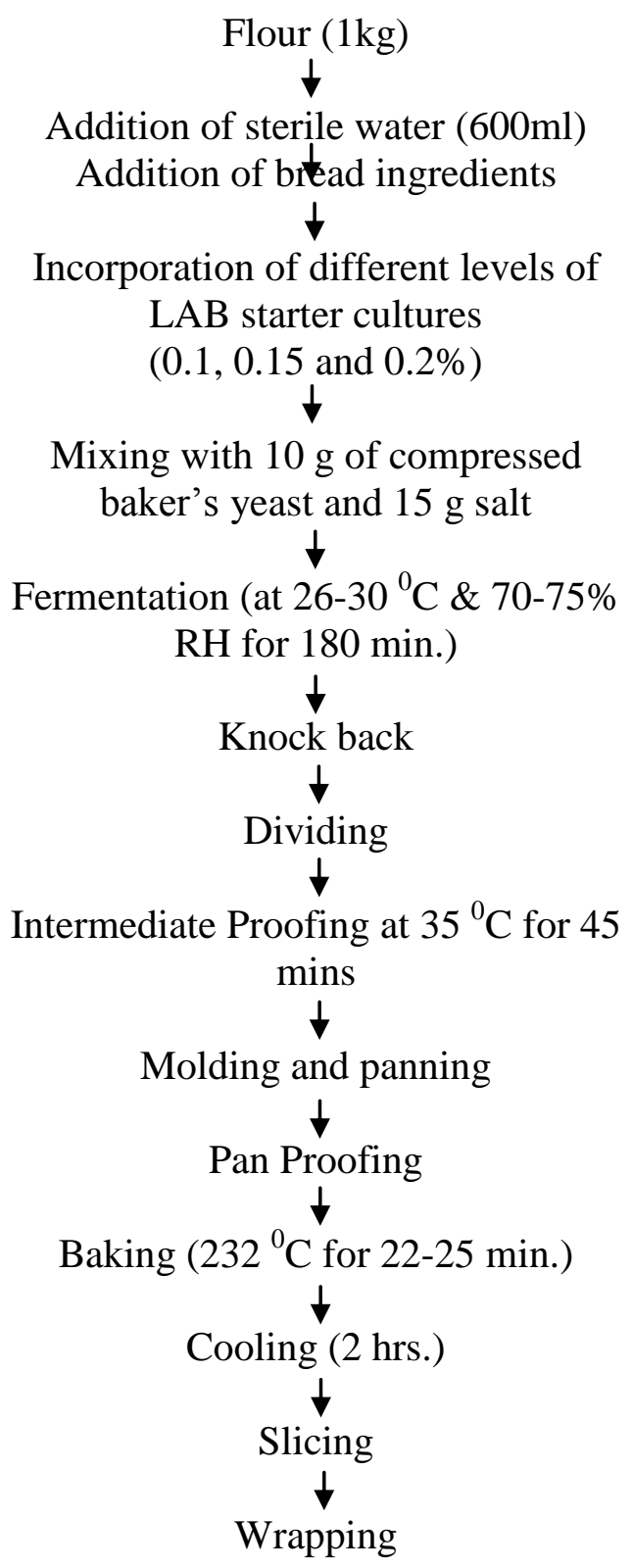


Table.1 Bread recipe used in bread production

\begin{tabular}{|c|l|l|}
\hline $\begin{array}{c}\text { Sr. } \\
\text { No. }\end{array}$ & \multicolumn{1}{|c|}{ Ingredients } & Weight (g) \\
\hline 1 & Flour (70\% whole wheat flour + 30\% Maida) & 100.0 \\
\hline 2 & Water & 60.0 \\
\hline 3 & Sugar & 2.0 \\
\hline 4 & Shortening & 2.0 \\
\hline 5 & Salt & 1.5 \\
\hline 6 & Yeast & 1.0 \\
\hline 7 & GMS & 0.3 \\
\hline
\end{tabular}

Table.2 Different levels of addition of starter culture

\begin{tabular}{|c|c|}
\hline Sample & Lactic acid starter culture $^{*}$ \\
\hline $\mathbf{T}_{\mathbf{1}}$ & $0.1 \%$ LAB starter culture \\
\hline $\mathbf{T}_{\mathbf{2}}$ & $0.15 \%$ LAB starter culture \\
\hline $\mathbf{T}_{\mathbf{3}}$ & $0.2 \%$ LAB starter culture \\
\hline
\end{tabular}

Table.3 Proximate analysis of flour

\begin{tabular}{|l|c|}
\hline Chemical Constituent (\%) & Mean value \\
\hline Moisture & 12.50 \\
\hline Crude fat & 1.80 \\
\hline Crude protein & 11.85 \\
\hline Ash & 1.53 \\
\hline Crude fiber & 2.04 \\
\hline NFE & 70.28 \\
\hline
\end{tabular}

Table.4 Bread making quality parameters of flour

\begin{tabular}{|l|c|}
\hline \multicolumn{1}{|c|}{ Parameters } & Result \\
\hline Alcohol acidity (\%) & 0.09 \\
\hline $\begin{array}{l}\text { Gluten content: \% (Wet } \\
\text { basis) }\end{array}$ & 31.54 \\
\hline $\begin{array}{l}\text { Gluten content: } \% \text { (Dry } \\
\text { basis) }\end{array}$ & 11.14 \\
\hline Peleshnke value (min) & 108 \\
\hline Sedimentation value (ml) & 21.67 \\
\hline Falling number (Sec) & 278 \\
\hline
\end{tabular}


Table.5 Rheological characteristics of sourdough prepared with different addition level of LAB starter cultures

\begin{tabular}{|l|c|c|c|c|c|c|}
\hline Sample & $\begin{array}{c}\text { Water } \\
\text { Absorption } \\
(\mathbf{\%})\end{array}$ & $\begin{array}{c}\text { Arrival } \\
\text { time (min) }\end{array}$ & $\begin{array}{c}\text { Departure } \\
\text { time (min) }\end{array}$ & $\begin{array}{c}\text { Peak } \\
\text { Time } \\
(\mathbf{m i n})\end{array}$ & $\begin{array}{c}\text { Dough } \\
\text { stability } \\
(\mathbf{m i n})\end{array}$ & $\begin{array}{c}\text { Softening } \\
\text { of dough } \\
(\mathbf{B U})\end{array}$ \\
\hline Control & 60.71 & 2.0 & 9.11 & 3.20 & 5.01 & 50.03 \\
\hline $\mathbf{T}_{\mathbf{1}}$ & 61.21 & 1.94 & 8.90 & 3.17 & 4.58 & 70.39 \\
\hline $\mathbf{T}_{\mathbf{2}}$ & 61.50 & 1.92 & 8.74 & 3.09 & 4.12 & 90.01 \\
\hline $\mathbf{T}_{\mathbf{3}}$ & 62.03 & 1.91 & 8.49 & 2.80 & 3.60 & 120.92 \\
\hline Mean & 61.3625 & 1.9425 & 8.81 & 3.065 & 4.3275 & 82.8375 \\
\hline SE & 0.092 & 0.006 & 0.043 & 0.030 & 0.101 & 5.064 \\
\hline CD at 5\% & 0.275 & 0.020 & 0.130 & 0.091 & 0.303 & 15.091 \\
\hline
\end{tabular}

Table.6 Extensibility of sour dough prepared with different level of LAB starter culture

\begin{tabular}{|l|c|c|}
\hline \multicolumn{1}{|c|}{ Sample } & $\begin{array}{c}\text { Mean Max. force 'resistance to } \\
\text { extension' (g) }\end{array}$ & $\begin{array}{c}\text { Mean Distance at Max. Force } \\
\text { 'Extensibility'(mm) }\end{array}$ \\
\hline Control $(\mathbf{C})$ & 84.6 & 37.2 \\
\hline $\mathbf{T}_{\mathbf{1}}$ & 69.9 & 38.1 \\
\hline $\mathbf{T}_{\mathbf{2}}$ & 67.6 & 42.7 \\
\hline $\mathbf{T}_{\mathbf{3}}$ & 76.2 & 35.4 \\
\hline Mean & 74.575 & 38.35 \\
\hline SE & 1.276 & 0.521 \\
\hline CD at 5\% & 3.804 & 1.554 \\
\hline
\end{tabular}

Table.7 Effects of different treatments on volume, specific volume, crust to crumb ratio of sour dough bread

\begin{tabular}{|l|c|c|c|}
\hline Treatments & Loaf volume $\mathbf{( m )}$ & Specific volume $\left(\mathbf{c m}^{\mathbf{3}} / \mathbf{g m}\right)$ & $\begin{array}{c}\text { Crust to crumb } \\
\text { ratio }\end{array}$ \\
\hline Control & 586 & 3.83 & 0.255 \\
\hline $\mathbf{T}_{\mathbf{1}}$ & 587 & 3.85 & 0.259 \\
\hline $\mathbf{T}_{\mathbf{2}}$ & 590 & 3.88 & 0.260 \\
\hline $\mathbf{T}_{\mathbf{3}}$ & 583 & 3.80 & 0.263 \\
\hline Mean & 586.5 & 3.84 & 0.25925 \\
\hline SE & 0.484 & 0.005 & 0.0005 \\
\hline CD at 5\% & 1.443 & 0.016 & 0.0016 \\
\hline
\end{tabular}


Table.8 Effect of different incorporation level of LAB starter culture on external sensorial characteristics of sour dough bread

\begin{tabular}{|l|c|c|c|c|c|c|c|}
\hline Sample & Volume & $\begin{array}{c}\text { Crust } \\
\text { colour }\end{array}$ & $\begin{array}{c}\text { Symmetry } \\
\text { of form }\end{array}$ & $\begin{array}{c}\text { Evenness } \\
\text { of bake }\end{array}$ & $\begin{array}{c}\text { Character } \\
\text { of crust }\end{array}$ & Aroma & $\begin{array}{c}\text { Overall } \\
\text { acceptability }\end{array}$ \\
\hline Control & 7.52 & 7.81 & 7.34 & 7.34 & 7.75 & 7.12 & 7.53 \\
\hline $\mathbf{T}_{\mathbf{1}}$ & 7.83 & 7.86 & 7.35 & 7.38 & 7.76 & 7.70 & 7.58 \\
\hline $\mathbf{T}_{\mathbf{2}}$ & 7.95 & 8.07 & 7.37 & 7.39 & 7.78 & 7.81 & 7.67 \\
\hline $\mathbf{T}_{\mathbf{3}}$ & 7.80 & 7.80 & 7.36 & 7.37 & 7.65 & 7.89 & 7.59 \\
\hline Mean & 7.775 & 7.885 & 7.355 & 7.370 & 7.735 & 7.630 & 7.592 \\
\hline SE & 0.030 & 0.021 & 0.002 & 0.003 & 0.009 & 0.058 & 0.0097 \\
\hline $\begin{array}{l}\text { CD at } \\
\mathbf{5 \%}\end{array}$ & 0.090 & 0.063 & 0.006 & 0.010 & 0.029 & 0.174 & 0.028 \\
\hline
\end{tabular}

Table.9 Effect of different levels of LAB starter culture on internal characteristics

\begin{tabular}{|l|c|c|c|c|c|}
\hline Sample & $\begin{array}{c}\text { Grain of } \\
\text { bread }\end{array}$ & $\begin{array}{c}\text { Colour of } \\
\text { crumb }\end{array}$ & Taste & Texture & $\begin{array}{c}\text { Overall } \\
\text { acceptability }\end{array}$ \\
\hline Control & 7.35 & 7.81 & 7.15 & 7.57 & 7.43 \\
\hline $\mathbf{T}_{\mathbf{1}}$ & 7.48 & 7.85 & 7.53 & 7.63 & 7.65 \\
\hline $\mathbf{T}_{\mathbf{2}}$ & 7.53 & 7.87 & 7.90 & 7.69 & 8.00 \\
\hline $\mathbf{T}_{\mathbf{3}}$ & 7.49 & 7.86 & 7.72 & 7.64 & 7.66 \\
\hline Mean & 7.4625 & 7.8475 & 7.575 & 7.6325 & 7.685 \\
\hline SE & 0.013 & 0.004 & 0.053 & 0.008 & 0.039 \\
\hline CD at 5\% & 0.039 & 0.013 & 0.160 & 0.024 & 0.117 \\
\hline
\end{tabular}

Table.10 Effect of different level of addition of LAB starter culture on $\mathrm{pH}$ and titrable acidity of sour dough bread

\begin{tabular}{|l|c|c|}
\hline \multicolumn{1}{|c|}{ Treatments } & $\mathbf{p H}$ & $\begin{array}{c}\text { Titrable acidity } \\
(\mathbf{m l ~ N a O H})\end{array}$ \\
\hline Control & 5.4 & 2.75 \\
\hline $\mathbf{T}_{\mathbf{1}}$ & 4.5 & 4.71 \\
\hline $\mathbf{T}_{\mathbf{2}}$ & 4.1 & 5.20 \\
\hline $\mathbf{T}_{\mathbf{3}}$ & 3.9 & 6.31 \\
\hline Mean & 4.475 & 4.7425 \\
\hline SE & 0.111 & 0.249 \\
\hline CD at 5\% & 0.332 & 0.743 \\
\hline
\end{tabular}


Table.11 Chemical composition of bread prepared with different addition level of LAB starter culture

\begin{tabular}{|l|c|c|c|c|c|c|c|}
\hline Sample & $\begin{array}{c}\text { Moisture } \\
(\mathbf{\%})\end{array}$ & $\begin{array}{c}\text { Protein } \\
(\mathbf{\%})\end{array}$ & $\begin{array}{c}\text { Fat } \\
(\mathbf{\%})\end{array}$ & $\begin{array}{c}\text { Total } \\
\text { Carbohydrates } \\
(\mathbf{\%})\end{array}$ & $\begin{array}{c}\text { Resistant } \\
\text { Starch } \\
(\boldsymbol{\%} \text { RS })\end{array}$ & $\begin{array}{c}\text { Ash } \\
(\mathbf{\%})\end{array}$ & $\begin{array}{c}\text { Crude } \\
\text { Fiber } \\
(\mathbf{\%})\end{array}$ \\
\hline Control & 31.02 & 8.02 & 0.81 & 45.02 & 3.21 & 2.01 & $\mathbf{9 . 9 1}$ \\
\hline $\mathbf{T}_{\mathbf{1}}$ & 35.13 & 7.91 & 0.73 & 39.51 & 4.76 & 2.11 & $\mathbf{9 . 8 4}$ \\
\hline $\mathbf{T}_{\mathbf{2}}$ & 35.80 & 8.01 & 0.7 & 37.90 & 5.54 & 2.14 & $\mathbf{9 . 9 0}$ \\
\hline $\mathbf{T}_{\mathbf{3}}$ & 36.53 & 7.9 & 0.76 & 36.7 & 6.04 & 2.15 & $\mathbf{9 . 9 1}$ \\
\hline Mean & 34.62 & 7.96 & 0.75 & 39.7825 & 4.8875 & 2.1025 & $\mathbf{9 . 8 9}$ \\
\hline SE & 0.415 & 0.010 & 0.007 & 0.618 & 0.208 & 0.010 & $\mathbf{0 . 0 0 5}$ \\
\hline CD at 5\% & $\mathbf{1 . 2 3 3}$ & $\mathbf{0 . 0 3 1}$ & $\mathbf{0 . 0 2 3}$ & $\mathbf{1 . 8 3 8}$ & $\mathbf{0 . 6 1 8}$ & $\mathbf{0 . 0 3 1}$ & $\mathbf{0 . 0 1 6}$ \\
\hline
\end{tabular}

Table.12 Effect of different addition level of LAB starter culture on organic acid content of bread

\begin{tabular}{|l|c|c|}
\hline Treatments & $\begin{array}{c}\text { Lactic acid } \\
(\mathbf{g} / \mathbf{1 0 0 g})\end{array}$ & $\begin{array}{c}\text { Acetic acid } \\
(\mathbf{g} / \mathbf{1 0 0 g})\end{array}$ \\
\hline Control & 0.007 & 0.010 \\
\hline $\mathbf{T}_{\mathbf{1}}$ & 0.224 & 0.041 \\
\hline $\mathbf{T}_{\mathbf{2}}$ & 0.350 & 0.072 \\
\hline $\mathbf{T}_{\mathbf{3}}$ & 0.493 & 0.093 \\
\hline Mean & 0.2685 & 0.054 \\
\hline SE & 0.034 & 0.006 \\
\hline CD at 5\% & 0.103 & 0.018 \\
\hline
\end{tabular}

Table.13 Total plate count at different storage intervals in bread samples

\begin{tabular}{|c|c|c|c|c|c|}
\hline \multirow{2}{*}{ Treatments } & \multicolumn{5}{|c|}{ Different storage intervals (hr.) } \\
\cline { 2 - 6 } & $\mathbf{0}$ & $\mathbf{2 4}$ & $\mathbf{4 8}$ & $\mathbf{7 2}$ & $\mathbf{9 6}$ \\
\hline Control & $4.2 \times 10^{1}$ & $8.5 \times 10^{1}$ & $1.9 \times 10^{2}$ & $2.7 \times 10^{2}$ & $3.5 \times 10^{2}$ \\
\hline $\mathbf{T}_{\mathbf{1}}$ & - & $4 \times 10^{1}$ & $1.0 \times 10^{2}$ & $1.4 \times 10^{2}$ & $1.9 \times 10^{2}$ \\
\hline $\mathbf{T}_{\mathbf{2}}$ & - & - & $5.5 \times 10^{1}$ & $9.5 \times 10^{1}$ & $1.3 \times 10^{2}$ \\
\hline $\mathbf{T}_{\mathbf{3}}$ & - & - & $4.3 \times 10^{1}$ & $8.2 \times 10^{1}$ & $1.0 \times 10^{2}$ \\
\hline
\end{tabular}

Table.14 Mold colony count at different storage intervals (hr.) in bread samples

\begin{tabular}{|l|c|c|c|c|c|}
\hline \multirow{2}{*}{ Treatments } & \multicolumn{5}{|c|}{ Different storage intervals (hr.) } \\
\cline { 2 - 6 } & $\mathbf{0}$ & $\mathbf{2 4}$ & $\mathbf{4 8}$ & $\mathbf{7 2}$ & $\mathbf{9 6}$ \\
\hline Control & $1.4 \times 10^{2}$ & $1.9 \times 10^{2}$ & $2.3 \times 10^{2}$ & $2.9 \times 10^{2}$ & $3.8 \times 10^{2}$ \\
\hline $\mathbf{T}_{\mathbf{1}}$ & $9 \times 10^{1}$ & $1.2 \times 10^{2}$ & $1.6 \times 10^{2}$ & $2.1 \times 10^{2}$ & $2.5 \times 10^{2}$ \\
\hline $\mathbf{T}_{\mathbf{2}}$ & $7 \times 10^{1}$ & $1.0 \times 10^{2}$ & $1.3 \times 10^{2}$ & $1.7 \times 10^{2}$ & $2.3 \times 10^{2}$ \\
\hline $\mathbf{T}_{\mathbf{3}}$ & $5 \times 10^{1}$ & $8.1 \times 10^{1}$ & $1.0 \times 10^{2}$ & $1.4 \times 10^{2}$ & $2.0 \times 10^{2}$ \\
\hline
\end{tabular}


Table.15 Theoretical energy value of sour dough bread

\begin{tabular}{|l|c|c|c|c|}
\hline \multirow{2}{*}{ Sample } & \multicolumn{3}{|c|}{ Energy (Kcal) } & Total energy \\
& Protein (Kcal) & Carbohydrate (Kcal) & Fat (Kcal) & \\
\cline { 2 - 5 } Control & 32.08 & 180.08 & 7.29 & 219.45 \\
\hline $\mathrm{T}_{1}$ & 31.64 & 158.04 & 6.57 & 196.25 \\
\hline $\mathrm{T}_{2}$ & 32.04 & 151.6 & 6.3 & 189.94 \\
\hline $\mathrm{T}_{3}$ & 31.6 & 146.8 & 6.84 & 185.24 \\
\hline
\end{tabular}

Fig.1 Extensibility curve of sour dough

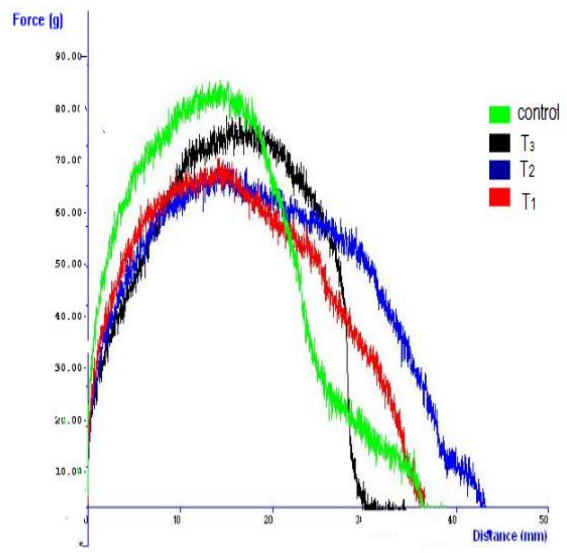

Fig.2 External sensorial characteristics of sour dough bread

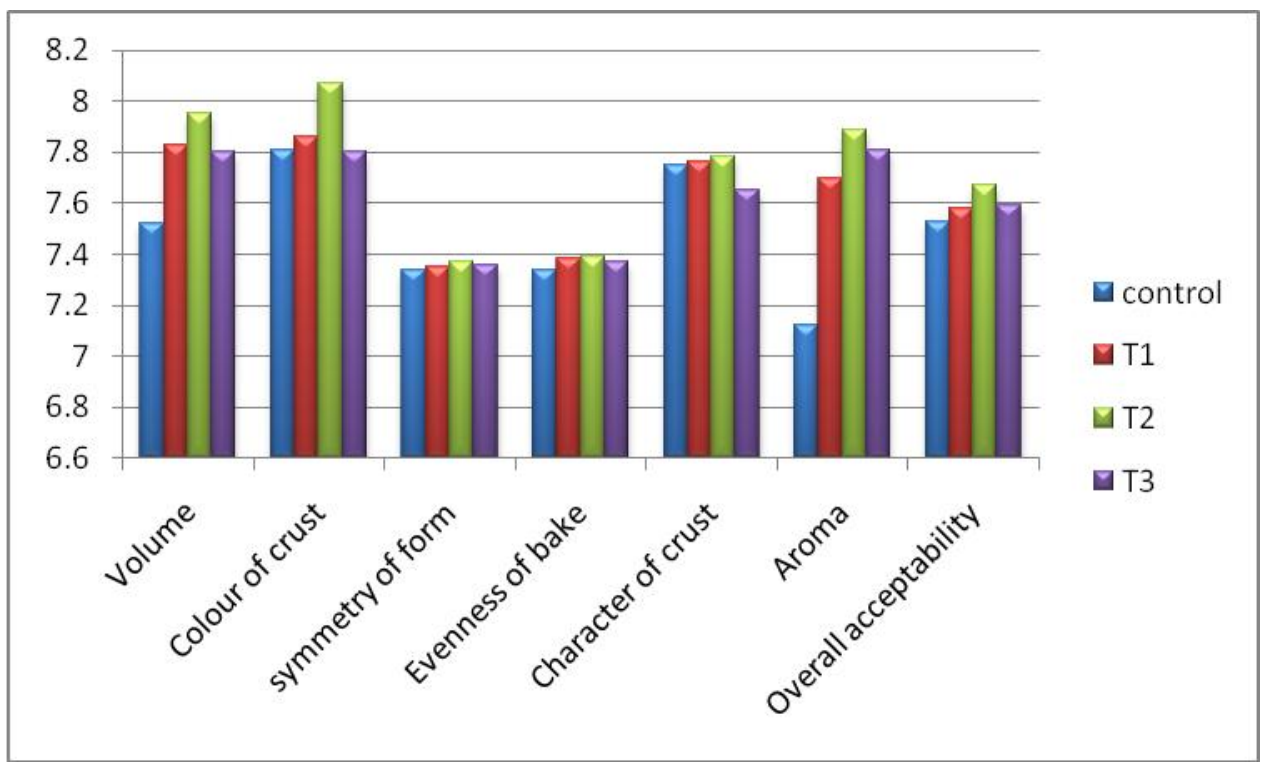


Fig.3 Internal sensorial characteristics of sour dough bread

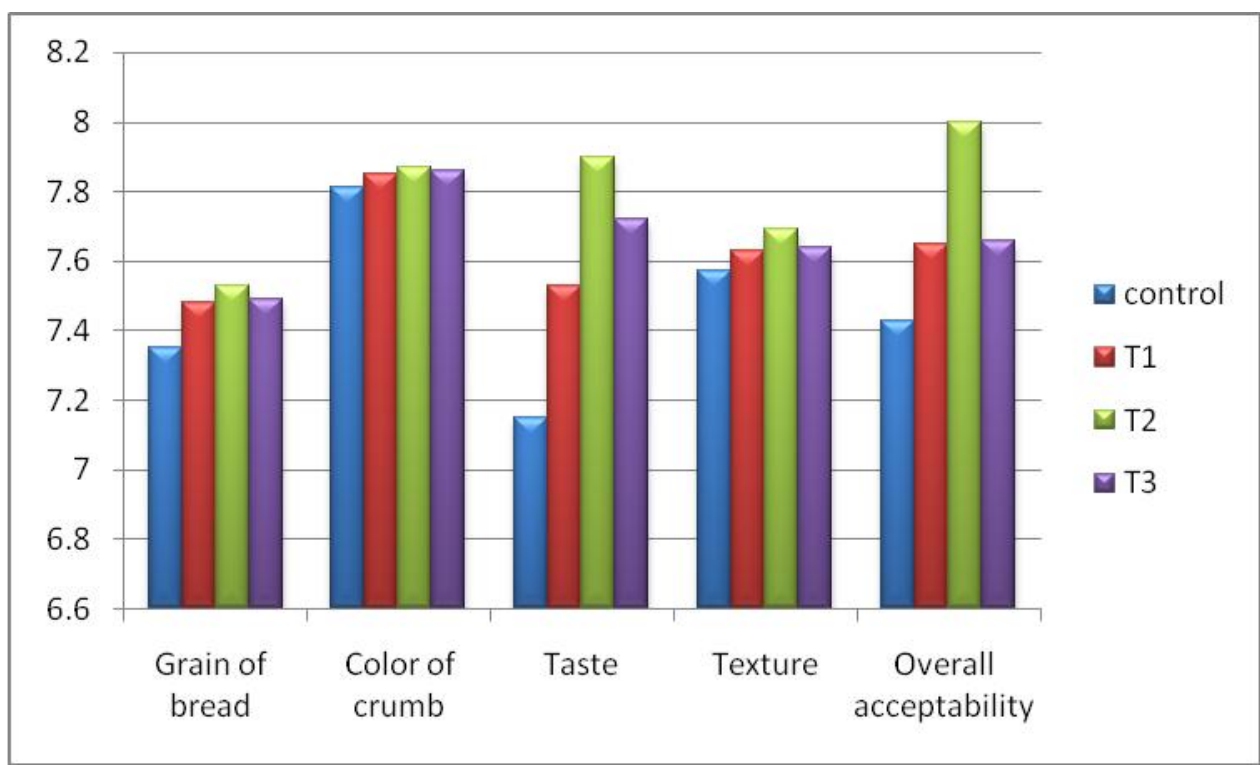

\section{Microbial analysis of sour dough bread}

Total plate count for Sour Dough breads at different storage intervals is given in the Table 13. It is evident that the total plate count was the highest $\left(3.5 \times 10^{2}\right)$ in breads prepared from control yeast culture. However, the total plate count was the lowest in Sour Dough bread sample $\mathrm{T}_{3}\left(1.0 \times 10^{2}\right)$ followed by $\mathrm{T}_{2}\left(1.3 \times 10^{2}\right)$ after 96 hours of storage. The microbiological analysis of breads at different storage intervals showed that the microbial loads decreased with the increase in the addition level of $\mathrm{LAB}$ starter cultures ranging from $1.9 \times 10^{2} \mathrm{CFU} / \mathrm{g}$ to $1.0 \times 10^{2} \mathrm{CFU} / \mathrm{g}$ from 0 to 96 hour. In $\mathrm{T}_{1}$, microbial colonies appeared after $24 \mathrm{~h}\left(4 \times 10^{1} \mathrm{CFU} / \mathrm{g}\right)$ and increased $\left(1.9 \times 10^{2} \mathrm{CFU} / \mathrm{g}\right)$ in bread at $96 \mathrm{~h}$ of storage. The colonies appeared after $48 \mathrm{~h}$ of storage in $\mathrm{T}_{2}$ and $\mathrm{T}_{3}$ ranging from $5.5 \times 10^{1}$ to $1.3 \times 10^{2} \mathrm{CFU} / \mathrm{g}, 4.3 \times 10^{1}$ to $1.0 \times 10^{2}$ for the sample $T_{2}$ and $T_{3}$ respectively. The total plate count for the control ranged from $4.2 \times 10^{1}$ to $3.5 \times 10^{2} \mathrm{CFU} / \mathrm{g}$. The Sour Dough breads produced with the addition of LAB starter cultures showed resistance against the growth of the contaminating microorganisms. The results of present study are in line with the study of Latif et al., (1996)
Yeast and mold count at different storage intervals in bread samples

Maximum number of yeast and mould colonies were recorded in control bread $(3.8 \times$ $10^{2}$ ). However, the fungal count was the lowest in breads prepared with the sample $\mathrm{T}_{3}$ $\left(2.0 \times 0^{2}\right)$ followed by breads prepared by sample $\mathrm{T}_{2}\left(2.3 \times 10^{2}\right)$ even after 96 hours of storage. The microbiological analysis of breads at different storage intervals showed that the microbial load decreased with increased addition level of LAB starter cultures. The mold count ranged from $1.4 \times$ $10^{2}$ to $3.8 \times 10^{2}$ for the control, $9 \times 10^{1}$ to $2.5 \times$ $10^{2}$ for $\mathrm{T}_{1}, 7 \times 10^{1}$ to $2.3 \times 10^{2}$ for $\mathrm{T}_{2}, 5 \times 10^{1}$ to $2.0 \times 10^{2}$ for the Sour Dough breads of sample $\mathrm{T}_{3}$. The results are in line with the findings of Hansen and Hansen (1994) (Table 14).

\section{Theoretical energy value of Sour Dough bread}

It is evident from the Table 15 that total energy value of control sample is $219.45 \mathrm{Kcal}$ while total energy value of Sour Dough bread $\mathrm{T}_{1}, \mathrm{~T}_{2}$ and $\mathrm{T}_{3}$ is 196.25, 189.94 and 185.24 Kcal respectively. Results showed that the 
total energy value of control was found to be higher than Sour Dough bread samples. This is due to increase in the resistant starch content in Sour Dough bread.

In conclusion, dough was fortified with LAB culture (Lactobacillus plantarum and Lactobacillus brevis) at $0.1 \%\left(\mathrm{~T}_{1}\right), 0.15 \%\left(\mathrm{~T}_{2}\right)$ and $0.2 \%\left(\mathrm{~T}_{3}\right)$ level of incorporation. The product prepared was evaluated for color, flavour, taste, texture, appearance and overall acceptability using semi-trained panel members on 9 point hedonic rating. It can be concluded that the LAB culture can be used successfully in preparation of sour dough bread at the level of $0.15 \%\left(\mathrm{~T}_{2}\right)$ without any undesirable changes in physical, chemical and organoleptic attributes of bread.

\section{References}

A. A. C. C. (2000). Approved Methods of the American Association of Cereal Chemists, 10th Ed. AACC, St. Paul, MN, USA.

A.O. A. C. (2000). Official methods of analysis, Association of Official Analytical Chemists. Washington DC.

Brighenti F., Casiraghi M.C., Baggio C., (1998). Resistant starch in the Italian diet. British Journal of Nutrition. 80: 333-341.

Brummer J. M, Lorenz K. (1991). European developments in wheat sourdoughs. Cereal Food World. 36:310-14.

Lorenz K. and Brummer J.M. (2003). Preferments and sourdoughs in German breads. In K. Kulp and K. Lorenz (Eds.), Handbook of dough fermentations. New York: Marcel Dekker Inc. pp. 247-267.

Catterall P., (1998). Flour milling. In: Cauvain, S.P., Young, L.S. (Eds.), Technology of Bread making. Blackie Academic and Professional, London, pp. 296-329.

Cauvain S. (2003). Bread making: an overview. In bread making improving quality. Woodhead Publication Ltd. 14.

Chavan R. S. and Chavan S. R. (2011). Sourdough Technology-A Traditional
Way for Wholesome Foods: A Review. Comprehensive Reviews in Food Science and Food Safety.10: 169-182.

Chavan R. S. and Jana A. (2008). Frozen dough for bread making - a review. International Journal of Food Science and Technology. 2:9-27.

Clarke C., Schober T., Dockery P., O'Sullican K. and Arendt E. (2004). Wheat sourdough fermentation: effects of time and acidification on fundamental rheological properties. Cereal Chemistry. 81(3): 409-417.

Clarke C.I., T.J. Chober, Eangst and E.K. Arendt. (2003). Use of response surface methodology to investigate the effects of processing conditions on sourdough wheat bread quality. European Journal of Food Research. Technol. 217:23-33

Collar C., Benedit, C. and Martinez-Anaya M.A. (1994). Microbial sour dough influence acidification properties and bread making potential of wheat dough. Journal of Food Science 59:629-33.

Corsetti A., B. Gobbetti B. De Marco, F. Balestrieri F., Paoletti and J. Rossi (2000). Combined effect of sourdough lactic acid bacteria and additives on bread firmness and staling. Journal of Agriculture and Food Chemisty. 48: 3044-3051.

Corsetti A., Lavermicocca P., Morea M., Baruzzi F., Tosti N., and Gobbetti M. (2001). Phenotypic and molecular identification and clustering of lactic acid bacteria and yeasts from wheat (species Triticum durum and Triticum aestivum) sourdoughs of Southern Italy. International Journal of Food Microbiology, 64:95-104.

Crowley P., Schober T., Clarke C., and Arendt E. (2002). Textural and structural properties of sourdough wheat bread. European Food Research Technology. 214: 489-296.

Dubravka N., Duska C., Martina B., Irena CB. And Nikolina C. (2011). Glycemic index and phenolics of partially-baked frozen bread with sourdough, International 
journal of Food Science and Nutrition, 62(1): 26-33

Ghadge P.N., Prasad K. and Kadam P.S. (2008).Effect of fortification on the physico- chemical and sensory properties of buffalo milk yoghurt. Electronic Journal of Environmental Agriculture of Food Chemistry., 7(5): 2890-2899.

Gobbetti M, Angelis M, Arnault P, Tossut P, Corsetti A, and Lavermicocca P. (1999). Added pentosans in bread making: fermentations of derived pentoses by sourdough lactic acid bacteria. Food Microbiology 16:409-18.

Gobbetti M, Corsetti A, and De Vincenzi S. (1995). The sourdough microflora. Characterization of homofermentative lactic acid bacteria based on acidification kinetics and impedance tests. Italian Journal of Food Science 2:91-102.

Gobbetti M, Corsetti A, Rossi J, La Rosa F, and Vincenzi S.D. (1994). Identification and clustering of lactic acid bacteria and yeasts from wheat sourdoughs of central Italy. Italian Journal of Food Science. 1:85-94.

Hansen B. and Hansen A. (1994). Volatile compounds in wheat sourdoughs produced by lactic acid bacteria and sourdough yeasts. Zeitchcriftfür Lebensmittel Unterschung und Forschung. 198:202-209.

Hoseney C. (1994). Principles of cereal science and technology. 2nd ed. St. Paul, Minn.: American Association of Cereal Chemists. 67: 561-568

Jenson I. (1998). Bread and baker's yeast. In: Wood BJB, editor. Microbiology of fermented foods. London: Blackie Academic and Professional. Pp. 172-98.

Katina K., Poutanen and Autio. (2004). Influence and interactions of processing conditions and starter culture on formation of acids, volatile compounds and amino acids in wheat sourdoughs. Cereal Chemistry. 81(5): 598-610.

Katina K., Salmenkallio M., Partanen P., Forssell R., and Autio K. (2006). Effects of sourdough and enzymes on staling of high-fibre wheat bread. Food Science and Technology. 39(5):479-491.

Katina K., E. Arendtb K.H. Liukkonen K. Autio, L. Flander and K. Poutanen. (2005). Potential of sourdough for healthier cereal products. Trends Food Science and Technology. 16: 104- 112.

Kent N.L. and Evers A.D (2000).Kent's technology of cereals (ISBN: 1855733617).

Latif S. (1996). Effect of different types of barley malt supplementation on the quality of bread. M.Sc. (Hons.) Thesis, Dept. Food Tech., Univ. Agri. Faisalabad, Pakistan.

Magnusson J., Storm K., Ross S., Sgogren J. and Schnurer J. (2003). Broad and complex antifungal activity among environmental isolates of lactic acid bacteria. Microbiology Lettuces. 219:129-35.

MessensW.,and De Vuyst L. (2002). Inhibitory substances produced by Lactobacilli isolated from sourdoughs - a review. International Journal of Food Microbiology. 72:31-43.

Ottogalli G., Galli A. and Foschino R. (1996). Italian bakery products obtained with sourdough: characterization of the typical microflora. Advances in Food Science. 18:131-44.

Panse G.V. and Sukhatme P.V. (1985).Statistical Method for Agricultural Workers. ICAR, New Delhi.

Park Y.H, Jung L.H., Jeon E.R. (2006). Quality characteristics of bread using sourdough. Journal of Food Science and Nutrition. 33:323-27.

Peter C.M. and James H.B. (2000).Cereal biotechnology (Edits) Woodhead Publishing Limited. 2:132.

Pomeranz Y. (1988). Wheat: chemistry and technology. AACC international. St. Paul MN. 1: 192-198

Qarooni J. (1996). Flat bread technology. New York: Chapman and Hall.1:99-101.

Rehman S., Paterson A and Piggott J.R. (2006).Flavour in sourdough breads: a review. Trends Food Science and 
Technology. 17:557-66.

Robert H., Gabriel V. D. Lefebvre, Rabier Y., Vayssier and C. Fontagne F. (2005). Study of the behaviour of Lactobacillus plantarum and Leuconostoc starters during a complete wheat sourdough bread making process. LWT-Food Science Technology. 39: 256-265.

Rothe M. and Ruttloff H. (1983). Aroma retention in modern bread production. Nahrung 27:505-12.

Ryan L. M., Bello F. D., Czerny M., Koehler P., Arendt E. K. (2009). Quantification of phenyllactic acid in wheat sourdough using high resolution gas chromatography-mass spectrometry. Journal of Agricultural and Food Chemistry. 57: 1060-4.

Salim-ur-Rehman, Haq N., Hussain S., Muhammad M. A., Anjum M. M. and Mian S. A. (2007). Effect of Sourdough Bacteria on the Quality and Shelf Life of Bread. Pakistan Journal of Nutrition 6(6): 562-565.

Schober T.J., Dockery P., and Arendt E.K., (2003). Model studies for wheat sourdough systems using gluten, lactate buffer and sodium chloride. European Food Research and Technology. 217, 235-243.

Shah P., G.M. Campbell, C. Dale and A. Rudder. (1999). Modelling bubble growth during proving of bread dough: predicting the output from the Chopin rheo fermentometer. In Campbell GM., C.
Webb, S.S. Pandiella, K. Niranjan. (eds.). Bubbles in food. Eagan Press, St Paul, Minn. 95-106.

Siddique, M.I. (1989). Physico-chemical Properties of Composite Flours for sourdough bread production. Ph.D. Thesis, Dept. Food Tech. Univ. Agri., Faisalabad

Tarar O.M. (1999). Studies on shelf life of bread using acidulants and their salts. M.Sc. (Hons.) Thesis, Dept of Food Tech. Univ. of Agriculture, Faisalabad.

Valerio F., Bellis P., Lonigro S. L., Visconti A. and Lavermicocca P. (2008). Use of Lactobacillus plantarum fermentation products in bread-making to prevent bacillus subtilisropy spoilage . International Journal Food Microbiology. 122:328- 32.

Wehrle K., Grau H. and Arendt E.K., (1997).Effects of lactic acid, acetic acid, and table salt on fundamental rheological properties of wheat dough. Cereal Chemistry. 74, 739-744.

Williams P.C., Haramein F.J., Nelson W. and Srivastava P. (1988). Particle size related physical properties of flour produced by smooth roll reduction of hard red spring wheat farina, Cereal Chemistry, 65(6), 486-492.

Yun H., Quail K., and Moss R. (1996). Physicochemical properties of wheat flours for white salted noodles. Journal of Cereal Science. 23:181-189.

\section{How to cite this article:}

Deshpande, H.W., S.D. Katke and Pathan M. Aziz Khan. 2019. Studies on Process Development and Quality Evaluation of Sour Dough Bread. Int.J.Curr.Microbiol.App.Sci. 8(02): 2224-2239. doi: https://doi.org/10.20546/ijcmas.2019.802.258 